\title{
OBITUARIES
}

Obituaries should be submitted by email to Ruth Doherty at r.doherty@nature.com.

All submitted obituaries should be 450 words maximum in length (apart from obituaries for

past presidents of the BDA where the length should be 800 words).

Content of the obituary is down to the individual author, and the approval of the family should

be given for the obituary prior to submission to the $B D J$.

\section{FRANK TONER}

\section{6-2015}

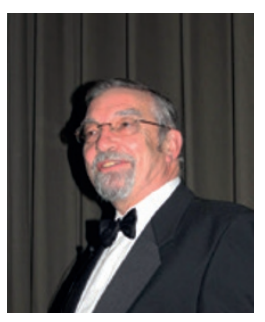

Frank was born and brought up in Edinburgh where he was the middle child in a family of five. He moved on to study at St Andrews University, electing to go to Dundee for

the clinical aspects of the course.

When he graduated in 1969, he started work in the practice in Cupar where he continued to practise until he retired. Like his father who was a headmaster, Frank knew the importance of education and was keen to pass on his knowledge to others. Early in his career he became an enthusiastic visiting tutor in Dundee Dental Hospital, where he was popular with students and staff.

Frank was a long serving member of Fife Area Dental Committee and Fife LDC, both of which he chaired, being elected Chair of the Scottish Conference of LDCs 2004, 2005. He served on SDPC, was a member of Fife Area Clinical Forum and a dental practice inspector. Latterly, Frank was Chairman of Scottish Dental Fund and in 2011 he was one of the first recipients of the Scottish Conference of LDCs' Lifetime Achievement Award in recognition of his contribution to the profession.

As if all of this was not enough, Frank had a very active life outside dentistry. He was a founder member of Cupar Sub-Aqua Club and an advanced diving instructor. He enjoyed curling with the Pitlessie Curling Club, and was a former Chairman of Cupar Round Table and member of Cupar Rotary Club.

This impressively long list of activities and achievements speaks not only to Frank's varied interests in life, but also to his keenness to be involved for the benefit of others.

The man himself had a great sense of humanity and fairness, having a healthy wariness of those in authority. He was especially irked when they perpetrated what he saw as an injustice, and in those instances he used his dry sense of humour to remind us that it was a good job he wasn't at all cynical!

He was a great raconteur with a seemingly endless stock of usually humorous stories, but above all, Frank was a family man and his wife Jackie, their three children and grandchildren were what mattered most to him.

\section{RAFIA KHANUM MALIK}

\section{9-2015}

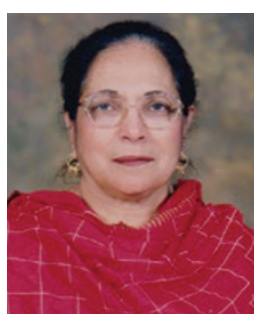

Dr Rafia Malik, the principal dentist of the Preventive Dental Practice, passed away on 18 January 2015 after a short respiratory illness. She was much loved by her patients.

Rafia was born in a small village called Kasur, just outside Lahore, Pakistan. Passionate about studying, she qualified as a dentist against all odds. She came to England in 1966 where she passed her statutory exam. Rafia then worked all over London where she met and married her husband, Jaffar Khan Malik. They then moved into their marital home just above her surgery on Falcon Road, Battersea. Rafia never forgot her passion for community dentistry. In 1984, she achieved her diploma in Dental Public Health from the Royal College of Surgeons.

Her career, spanning four decades, encompassed many different aspects of the profession. She was appointed as project director of Baqai Dental College, Karachi in November 1988 and remained as their Vice Principal from 1991-1993. Dr Malik prepared the new syllabus and curriculum, introduc- ing two new subjects - community dentistry and preclinical training - to produce professionally sound dental surgeons. Her original students remember her passion and dedication.

In 1994 she was awarded an honorary degree, DSc, by the Open International University of Alternative Medecine, Sri Lanka. She founded her Institute of Preventive Dentistry and Dental Public Health in Karachi, Pakistan in 1987 to produce paradental dental hygienists. Her staff are still committed to honouring her vision of preventive dentistry in the subcontinent, providing quality education and training. Rafia wrote many clinical books including Notes on preventive dentistry and Four points plan for the prevention of dental diseases. There is no doubt she has made a huge contribution to community dentistry and NHS dentistry.

As well as being a popular practitioner in the UK, she frequently ran mobile dental clinics and dental camps to help the underprivileged abroad. Her outlook on life was spiritual and altruistic. Her generosity knew no bounds. At her practice in Beddington, she also held many events to help the younger patients enjoy maintaining their oral health and create awareness in the community. In 2001 she lost her beloved husband, yet the birth of her grandson gave Rafia a new lease of life. She was a devoted wife, inspirational mother and wonderful grandmother. Her legacy is strong and will remain so. Her daughter qualified as a dentist in 2011 from Kings College London and began working at the practice with her mother after finishing her vocational training.

Her team at the Preventive Dental Practice in Beddington remember Dr Rafia Malik as 'a very compassionate and caring person, strong, determined and thoughtful with a great giggly laugh ... she will be sorely missed.' She is survived by her daughter Maezama and grandson Sufyan.

Maezama Malik 